\title{
The Effectiveness of Yoga on Patients with Breast Cancer in Reducing Symptoms of Stress: Evidence- Based Review
}

\author{
Hassan Izzeddin Sarsak* \\ Department of Occupational Therapy, School of Rehabilitation Sciences, University of Jordan, Jordan
}

*Corresponding author: Hassan Izzeddin Sarsak, Department of Occupational Therapy, University of Jordan, Jordan, Batterjee Medical College, Saudi Arabia

Submission: 阱 October 09, 2018; Published: 眥 October 17, 2018

\begin{abstract}
This study was conducted to examine the scientific evidence regarding the effectiveness of yoga intervention on stress reduction for patients with breast cancer. PICO method was used to develop research question and a thorough review was conducted to identify most relevant evidence-based research related to the effectiveness of yoga on patients with breast cancer in reducing symptoms of stress. Our review revealed four studies suggesting that yoga exercises may reduce stress related symptoms associated with breast cancer patients. Yoga exercises are effective and helpful and could reduce symptoms of stress in patients with breast cancer.
\end{abstract}

Keywords: Yoga; Breast cancer; Stress; Distress mood

\section{Introduction}

Patients with breast cancer may have psychological and physical discomfort. Emotional responses may create barriers that prevent these patients from fully participating in their daily routines. Yoga enhances the patient's ability to cope with their stressful situation Banerjee [1] \& Moadel [2]. The purpose of this study was to examine the scientific evidence regarding the effectiveness of yoga intervention on stress reduction for patients with breast cancer. For this study, we created a clinical/research PICO question (Population, Intervention, Comparison, and Outcome), a key to evidence-based decision Richardson et al. [3]. The PICO formed for our study is as follows:
P: For patients with breast cancer
I: Does a yoga program
C: Compared to other treatments
O: Reduce the symptoms of stress?

\section{Methods}

Review of literature and search strategy- A research has been made in the following databases: Ovid (MEDLINE, Psych INFO, and Global Health), and CINAHL. Keywords and Search items used to search articles for our study were Yoga, breast cancer, stress, distress mood. Four articles were selected related to the effectiveness of yoga on patients with breast cancer in reducing symptoms of stress. All articles were related to our PICO question. After all, the strongest evidence-based article was chosen using hierarchy of levels of evidence in evidence-based practice Hughes [4].

\section{Results}

Table $1 \& 2$ show a summary of the four articles in relation to our PICO.

Table 1: A summary of reviewed articles in relation to our PICO.

\begin{tabular}{|c|l|l|}
\hline \multicolumn{1}{|c|}{ Article } & \multicolumn{1}{|c|}{ Our PICO } & \multicolumn{1}{c|}{ Relate to PICO (Article PICO) } \\
\hline \multirow{4}{*}{ Banerjee et al. [1] } & P: For patients with breast cancer & P: Patients with breast cancer \\
\cline { 2 - 3 } & I: Does a yoga program & I: Does a yoga program and counseling \\
\cline { 2 - 3 } & C: Compared to other treatments & C: Supportive counseling \\
\cline { 2 - 3 } & O: Reduce the symptoms of stress? & $\begin{array}{l}\text { O: Yoga group reduced the symptom of anxiety, depression, stress, and } \\
\text { the level of DNA damage }\end{array}$ \\
\cline { 2 - 3 } & $\begin{array}{l}\text { Using yoga as an intervention for patients with breast cancer can sig- } \\
\text { nificantly reduce the symptom of stress. }(p<.001)\end{array}$ \\
\hline
\end{tabular}




\begin{tabular}{|c|c|}
\hline \multirow{10}{*}{ Moadel et al. [2] } & P: Patients with breast cancer \\
\hline & I: Does a yoga program \\
\hline & C: Standard care \\
\hline & $\begin{array}{l}\text { 0: Yoga group has significant improvement in emotional well-being and } \\
\text { reduced distress mood (anxiety/sadness; irritability) }\end{array}$ \\
\hline & Yoga intervention group had significant improvement in: \\
\hline & *emotional well-being $(\mathrm{p}<.015)$ \\
\hline & ${ }^{*}$ spiritual well-being $(\mathrm{p}<.009)$ \\
\hline & *distress mood: \\
\hline & anxiety/sadness $(\mathrm{p}<.046)$ \\
\hline & irritability $(\mathrm{p}<.027)$ \\
\hline \multirow{5}{*}{ Reed et al. [6] } & P: Patients with breast cancer \\
\hline & I: Does a yoga program \\
\hline & C: X (no comparison) \\
\hline & $\begin{array}{l}\text { O: yoga can reduce the symptoms of stress for gastrointestinal, emo- } \\
\text { tional irritability, and cognitive disorganization, but the decrease was } \\
\text { not significant }\end{array}$ \\
\hline & $\begin{array}{l}\text { Using yoga as an intervention for patients with breast cancer may re- } \\
\text { duce the symptoms of stress, emotional irritability, and cognitive dis- } \\
\text { organization }\end{array}$ \\
\hline \multirow{5}{*}{ Carson et al. [5] } & P: Patients with metastatic breast cancer \\
\hline & I: Does a yoga program \\
\hline & C: X (no comparison) \\
\hline & $\begin{array}{l}\text { O: Yoga did not consistently and significantly reduce the symptoms of } \\
\text { stress. }\end{array}$ \\
\hline & $\begin{array}{l}\text { For treatment effects on daily outcomes after } 8 \text { weeks, the yoga pro- } \\
\text { gram did not significantly reduce the daily distress or increase daily } \\
\text { relaxation for patients with metastatic breast cancer. However, daily } \\
\text { invigoration was significantly increased. }\end{array}$ \\
\hline
\end{tabular}

Table 2: Summary of reviewed articles.

\begin{tabular}{|c|c|c|c|c|}
\hline & Banerjee et al. [1] & Moadel et al. [2] & Reed et al. [6] & Carson et al. [5] \\
\hline Design & RCT & RCT & Crossover & Pre-post \\
\hline Level of evidence & level II & level II & level III & level III \\
\hline Total Sample size & $\mathrm{N}=58$ & $N=164$ & $\mathrm{~N}=36$ & $\mathrm{~N}=13$ \\
\hline Mean age of subjects & $47 \pm 1.1$ & $55.11 \pm 10.07$ & 51.18 & 59 \\
\hline Interventions/per week (minutes) & 90 & 90 & 75 & 960 \\
\hline Total intervention time (weeks) & 6 & 12 & 7 & 8 \\
\hline Measurement Time & $\begin{array}{l}\text { Baseline } \\
6 \text { weeks }\end{array}$ & $\begin{array}{l}\text { Baseline } \\
1 \text { month } \\
3 \text { months } \\
6 \text { months }\end{array}$ & $\begin{array}{l}\text { Baseline } \\
7 \text { weeks }\end{array}$ & $\begin{array}{l}\text { Baseline } \\
8 \text { weeks/ } \\
\text { the same day } \\
\text { the next day }\end{array}$ \\
\hline The outcome for reducing stress & Significant & Significant & Not significant & Not significant \\
\hline
\end{tabular}




\section{Discussion}

Banerjee et al. [1] which examined the effects of an integrated yoga program in modulating psychological stress and radiationinduced genotoxic stress in breast cancer patients undergoing radiotherapy was selected as the strongest evidence in our study. It was a level II randomized control trial (RCT) with significance level of $\mathrm{P}<.001$ after 6 weeks. Thus, clinical guidelines, recommendations, a plan and audit tool have been developed in our study to implement yoga in clinics (Table 3).

\section{Conclusion}

Our review suggested that yoga exercises are effective and helpful and could reduce symptoms of stress in patients with breast cancer $[5,6]$. Thus, clinical guidelines, recommendations, a plan and audit tool have been created in our study to implement yoga programs in clinics. The clinical guidelines for recommended intervention, the plan, and the audit tool recommend therapists to apply yoga exercises with patients with breast cancer and stress.

Table 3: A summary of recommendations, plan, and audit tool.

\begin{tabular}{|c|c|c|c|c|}
\hline Recommendation & Implementation Plan & Criteria & Audit Method & Compliance Plan \\
\hline $\begin{array}{l}\text { 1. Three therapists will at- } \\
\text { tend Yoga program train- } \\
\text { ing. }\end{array}$ & $\begin{array}{l}\text { Three therapists will be recruited } \\
\text { and scheduled to attend the Yoga } \\
\text { program training. }\end{array}$ & $\begin{array}{l}\text { The three therapists will } \\
\text { complete the Yoga training } \\
\text { within two months. }\end{array}$ & $\begin{array}{l}\text { A training file, which will be } \\
\text { reviewed weekly, includes } \\
\text { attendance sheets for each } \\
\text { training session and a cer- } \\
\text { tificate for completing the } \\
\text { two-month training. }\end{array}$ & $\begin{array}{l}\text { If the therapists do not } \\
\text { attend the program, a } \\
\text { note will be recorded } \\
\text { on the Yoga training } \\
\text { file. }\end{array}$ \\
\hline $\begin{array}{l}\text { 2. The trained therapists } \\
\text { will make one set of Yoga } \\
\text { movements for a } 90 \text {-minute } \\
\text { session. }\end{array}$ & $\begin{array}{l}\text { The trained therapists develop a } \\
\text { serious of Yoga movements for } 90 \\
\text { minutes based on their training } \\
\text { program. }\end{array}$ & $\begin{array}{l}\text { The set of Yoga movements } \\
\text { will be completed in one } \\
\text { month after the trainers } \\
\text { finish their training. }\end{array}$ & $\begin{array}{l}\text { Within one month, the } \\
\text { trainers will complete a } \\
\text { template that includes pur- } \\
\text { pose, procedure, and Yoga } \\
\text { movement patterns for this } \\
\text { program. }\end{array}$ & $\begin{array}{l}\text { If the template is not } \\
\text { completed within one } \\
\text { month, a note will be } \\
\text { recorded in the Yoga } \\
\text { plan file }\end{array}$ \\
\hline $\begin{array}{l}\text { 3. The trained therapists } \\
\text { will make a Yoga teaching } \\
\text { video. }\end{array}$ & $\begin{array}{l}\text { Based on the template, two trained } \\
\text { therapists will perform Yoga move- } \\
\text { ments, and one trained therapist } \\
\text { will verbally explain the teaching } \\
\text { video. }\end{array}$ & $\begin{array}{l}\text { The teaching video will } \\
\text { be completed within two } \\
\text { weeks. }\end{array}$ & $\begin{array}{l}\text { The video will be available } \\
\text { for every staff member. }\end{array}$ & $\begin{array}{l}\text { If the video is not } \\
\text { completed within two } \\
\text { weeks, a note will be } \\
\text { recorded in the Yoga } \\
\text { plan file. }\end{array}$ \\
\hline $\begin{array}{l}\text { 4. The trained therapists } \\
\text { will teach other staff mem- } \\
\text { bers how to perform the } \\
\text { Yoga program. }\end{array}$ & $\begin{array}{l}\text { For one hour during every lunch } \\
\text { break, staff members will separate } \\
\text { into groups (@five members for } \\
\text { each group) to learn each move- } \\
\text { ment pattern. }\end{array}$ & $\begin{array}{l}\text { Within one month, } 100 \% \\
\text { of staff members will learn } \\
100 \% \text { of the Yoga move- } \\
\text { ments in this program. }\end{array}$ & $\begin{array}{l}\text { The trained therapist will } \\
\text { weekly review an attendant } \\
\text { sheet for each learning ses- } \\
\text { sion within the one-month } \\
\text { training. }\end{array}$ & $\begin{array}{l}\text { If the therapists do not } \\
\text { attend the learning } \\
\text { session, a note will be } \\
\text { recorded in his/her } \\
\text { training file. }\end{array}$ \\
\hline $\begin{array}{l}\text { 5. All staff members will } \\
\text { present the Yoga program. }\end{array}$ & $\begin{array}{l}\text { Staff members will perform the set } \\
\text { of Yoga movements one by one for } \\
\text { the three trained therapists. }\end{array}$ & $\begin{array}{l}\text { The staff members should } \\
\text { reach an } 80 \% \text { accuracy of } \\
\text { all movements during the } \\
\text { Yoga performance. }\end{array}$ & $\begin{array}{l}\text { The trained therapists will } \\
\text { report the competence level } \\
\text { of each staff member. }\end{array}$ & $\begin{array}{l}\text { Those staff members } \\
\text { who fail to pass with an } \\
80 \% \text { accuracy will have } \\
\text { to review the teaching } \\
\text { video and again per- } \\
\text { form the movements } \\
\text { for the trained thera- } \\
\text { pists in two weeks. }\end{array}$ \\
\hline
\end{tabular}

\section{References}

1. Banerjee B, Rao R, Gopinath KS, Kumar A, Hegde S (2007) Effects of an integrated yoga program in modulating psychological stress and radiation-induced genotoxic stress in breast cancer patients undergoing radiotherapy. Integrative Cancer Therapies 6(3): 242-250.

2. Moadel AB, Shah C, Rosett J, Harris MS, Patel SR, et al. (2007) Randomized controlled trial of yoga among a multiethnic sample of breast cancer patients: effect on quality of life. Journal of Clinical Oncology 25(28): 4387-4395.

3. Richardson WS, Wilson MC, Nishikawa J, Hayward RS (1995) The well- built clinical question: a key to evidence-based decision. ACP Journal Club 123(3): A12-A13.

4. Hughes I (2006) Action research in healthcare: what is the evidence? ALAR Journal 11(1): 29-39.

5. Carson JW, Carson KM, Porter LS, Keefe FJ, Shaw H, et al. (2007) Yoga for women with metastatic breast cancer: results from a pilot study. Journal of Pain and Symptom Management 33(3): 331-341.

6. Reed SN, Carlson LE, Daroux LM, Aldous S (2006) A pilot study of yoga for breast cancer survivors: physical and psychological benefits. Psycho-Oncology 15(10): 891-897. 
Creative Commons Attribution 4.0 International License

For possible submissions Click Here

Submit Article
EPMR

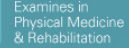

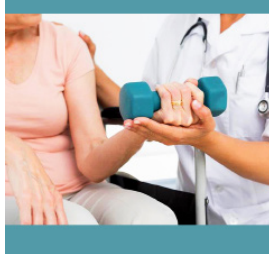

Examines in Physical Medicine and Rehabilitation: Open Access

\section{Benefits of Publishing with us}

- High-level peer review and editorial services

- Freely accessible online immediately upon publication

- Authors retain the copyright to their work

- Licensing it under a Creative Commons license

- Visibility through different online platforms 